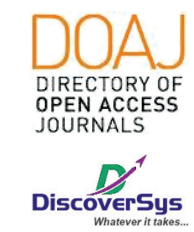

Published by DiscoverSys

\section{Hubungan antara Mean Platelet Volume (MPV) dengan klinis sepsis neonatorum di RSUD Wangaya, Bali, Indonesia}

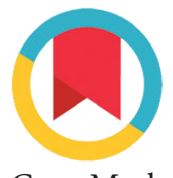

CrossMark

\author{
Stanley Haryono, ${ }^{*}$ I Wayan Bikin Suryawan, Anak Agung Made Widiasa
}

\section{ABSTRACT}

Background: Neonatal sepsis is a disease that contributes significantly to infant morbidity and mortality, where the diagnosis is not specific to other diseases. In a state of sepsis, it is known that platelet production will increase due to the destruction of platelets so that there is a difference in platelet size or Mean Platelet Volume (MPV). This study aims to determine the relationship between MPV and clinical neonatal sepsis at Wangaya Hospital, Bali, Indonesia.

Methods: This study used a cross-sectional study design with 47 patients at Wangaya Hospital, Denpasar, in June-September 2019. The inclusion criteria were neonates with suspicion of sepsis, and the exclusion criteria were neonates who received previous antibiotic therapy, neonates who had previously received blood transfusions., neonates with severe congenital anomalies were selected using a consecutive sampling technique. The sample was divided into 2 groups: clinical sepsis and non-clinical sepsis, MPV used a limit value of $10.2 \mathrm{fl}$, and data were analyzed by SPSS version 23 for Windows.

Results: Most of the patients were male $(66.7 \%)$, underwent section labor (77.8\%), preterm birth (66.7\%), birth weight (BBL) $<2,500$ grams (62.9\%), and asphyxia (62.9\%) in the non-septic group. Meanwhile, most of the sepsis group underwent labor (85\%), preterm birth (70.0\%), and asphyxia (75.0\%). The results showed that there was a significant relationship between the MPV value and the risk of neonatal sepsis (RR: $8.16 ; 95 \%$ Cl: $2.1-30.5 ; p=0.003$ ).

Conclusion: The results of this study concluded that there was a significant difference between the MPV value and the incidence of neonatal sepsis.
Departemen IImu Kesehatan Anak, Rumah Sakit Umum Daerah (RSUD) Wangaya, Denpasar, Bali, Indonesia

*Korespondensi: Stanley Haryono, Departemen IImu Kesehatan Anak, Rumah Sakit Umum Daerah (RSUD) Wangaya, Denpasar, Bali, Indonesia; stanleyharyono@gmail.com

Diterima: $17-10-2019$

Disetujui: $10-06-2020$

Diterbitkan: 01-08-2020

Keywords: Sepsis, Neonates, Mean Platelet Volume.

Cite This Article: Haryono, S., Suryawan, I.W.B., Widiasa, A.A.M. 2020. Hubungan antara Mean Platelet Volume (MPV) dengan klinis sepsis neonatorum di RSUD Wangaya, Bali, Indonesia. Intisari Sains Medis 11(2): 675-679. D0I: 10.15562/ism.v11i2.646

\title{
ABSTRAK
}

Latar Belakang: Sepsis neonatorum merupakan penyakit yang berkontribusi besar terhadap angka morbiditas dan mortalitas bayi dimana diagnosisnya bersifat tidak spesifik dengan penyakit lain. Pada keadaan sepsis, produksi trombosit diketahui akan meningkat akibat penghancuran trombosit sehingga adanya perbedaan ukuran trombosit atau Mean Platelet Volume (MPV). Penelitian ini bertujuan untuk mengetahui hubungan antara MPV dengan klinis sepsis neonatorum di RSUD Wangaya, Bali, Indonesia.

Metode: Penelitian menggunakan rancangan penelitian potong lintang terhadap 47 pasien yang bertempat di RSUD Wangaya, Denpasar pada bulan Juni-September 2019. Kriteria inklusi adalah neonatus dengan kecurigaan sepsis dan kriteria ekslusi adalah neonatus yang mendapat terapi antibiotik sebelumnya, neonatus yang pernah menerima transfusi darah sebelumnya, neonatus dengan anomali kongenital berat yang dipilih menggunakan teknik consecutive sampling. Sampel dibagi menjadi 2 kelompok yaitu klinis sepsis dan bukan klinis sepsis, MPV menggunakan nilai batas $10,2 \mathrm{fl}$, dan data dianalisis dengan SPSS versi 23 untukWindows. Hasil: Sebagian besar pasien berjenis kelamin laki-laki $(66,7)$, menjalani persalinan seksio $(77,8 \%)$, lahir preterm $(66,7 \%)$, berat badan lahir (BBL) < 2.500 gram $(62,9 \%)$, dan asfiksia $(62,9 \%)$ pada kelompok tidak sepsis. Sedangkan pada kelompok sepsis sebagian besar menjalani persalinan seksio $(85, \%)$, lahir preterm $(70,0 \%)$, dan asfiksia (75,0\%). Hasil penelitian menunjukkan bahwa terdapat hubungan yang bermakna antara nilai MPV terhadap resiko terjadinya sepsis neonataroum (RR: 8,16; 95\%IK: 2,1-30,5; $p=0,003$ ).

Kesimpulan: Hasil penelitian ini menyimpulkan bahwa terdapat perbedaan yang bermakna antara nilai MPV dengan kejadian sepsis neonatarum.

\section{Kata Kunci: Sepsis, Neonatus, Mean Platelet Volume}

Cite Pasal Ini: Haryono, S., Suryawan, I.W.B., Widiasa, A.A.M. 2020. Hubungan antara Mean Platelet Volume (MPV) dengan klinis sepsis neonatorum di RSUD Wangaya, Bali, Indonesia. Intisari Sains Medis 11(2): 675-679. D0I: 10.15562/ism.v11i2.646

\section{PENDAHULUAN}

Sepsis neonatorum merupakan sindrom klinis yang timbul akibat respon inflamasi sistemik terjadi akibat infeksi bakteri, virus, jamur ataupun parasit pada bulan pertama kehidupan. ${ }^{1}$ Sepsis neonatorum 
berkontribusi besar terhadap angka morbiditas dan mortalitas neonatus dimana World Health Organization (WHO) memperkirakan sekitar 1 juta kematian neonatus pertahunnya disebabkan oleh sepsis neonatorum dan $42 \%$ terjadi pada minggu pertama kehidupan. ${ }^{2}$

Angka kejadian sepsis neonatorum bervariasi, di negara maju 1-10/1000 kelahiran hidup dan lebih tinggi di negara berkembang yaitu 1-50/1000 kelahiran hidup. ${ }^{2}$ Telah diketahui neonatus yang lahir prematur atau lahir dengan berat badan lahir yang rendah beresiko mengalami sepsis neonatorum lebih tinggi. ${ }^{2}$ Di Indonesia penelitian yang dilakukan di Rumah Sakit Cipto Mangunkusumo (RSCM) Jakarta dalam periode Januari- September 2005 angka kejadian sepsis neonatorum 13,68\% dari seluruh kelahiran hidup dengan tingkat angka kematian 14,8\%. ${ }^{3}$ Di Rumah Sakit Umum Pusat Sanglah dalam periode Januari- Desember 2008, angka kejadian sepsis neonatorum 5\% dengan tingkat angka kematian $28,3 \%{ }^{2,3}$

Gejala-gejala awal dari sepsis neonatorum tidak spesifik dan saling tumpang tindih dengan penyakit yang lain. Berbagai temuan klinis dan laboratorium dapat membantu dalam diagnosis sepsis, tetapi untuk diagnosis pastinya dipastikan dengan pemeriksaan kultur darah yang positif. ${ }^{4}$ Kultur darah membutuhkan waktu yang lama untuk memberikan hasil dan dapat false positive oleh karena kontaminasi ataupun hasilnya negatif walaupun dengan klinis infeksi yang parah. ${ }^{1,4}$ Penggunaan antibiotik, jika menunggu hasil kultur akan terlambat untuk penangganan kasus sepsis neonatorum, maka pemberian secara empiris dilakukan tetapi dengan skenario seperti ini akan menyebabkan penggunaan antibiotik yang berlebihan sehingga beresiko meningkatkan resistensi bakteri. ${ }^{1,4}$ Maka dari itu pencarian biomarker non kultur terus dicari seperti halnya parameter dari hitung trombosit. ${ }^{5}$

Trombosit merupakan komponen darah yang berfungsi untuk proses menghentikan perdarahan dan proses koagulasi, tetapi selain itu dari hasil penelitian ditemukan trombosit mempunyai peran dalam proses inflamasi penyakit infeksi akut dan kronis maka pemeriksaan parameter trombosit dapat memberikan gambaran untuk penyakit tersebut. ${ }^{5}$ Salah satu parameter trombosit yang dapat dinilai adalah Mean Platelet Volume (MPV). Pemeriksaan MPV maupun rasio trombosit seperti Platelet to Lymphocyte Ratio (PLR) sudah ada sejak tahun 1970 dan sering diperiksa dalam pemeriksaan darah rutin dan telah dipelajari mempunyai hubungan dengan beberapa penyakit, seperti pada keganasan, maupun sepsis., ${ }^{5,6}$ Produksi trombosit pada sepsis akan ditingkatkan oleh sumsum tulang karena adanya peningkatan pemakaian dan penghancuran trombosit sehingga adanya perbedaan ukuran trombosit dimana trombosit muda mempuyai ukuran lebih besar dan trombosit tua ukurannya lebih kecil maka meningkatkan nilai MPV. $^{5-7}$ MPV juga memberiksan nilai informasi tentang infeksi yang invasif dan infeksi yang tidak berespon dengan antibiotik. ${ }^{8}$

Berdasarkan pemaparan di atas diketahui bahwa beberapa penelitian terdahulu yang mencoba untuk mencari hubungan MPV dengan sepsis neonatorum menunjukkan hasil yang beragam. Berkaitan dengan hal tersebut maka penelitian ini bertujuan untuk mencari tahu hubungan MPV dengan kejadian sepsis neonatorum di RSUD Wangaya, Bali, Indonesia.

\section{METODE}

Penelitian ini merupakan penelitian analitik observasional dengan desain cross-sectional untuk mengetahui hubungan nilai MPV dengan klinis sepsis neonatorum. Penelitian ini dilakukan di ruang perinatologi dan NICU RSUD Wangaya Kota Denpasar sejak bulan Juni 2019 - September 2019.

Besar sampel menggunakan rumus besar sampel dengan koefisein korelasi minimal yang dianggap bermakna 0,5, kesalahan tipe 1 ditetapkan 5\%, hipotesis satu arah, kesalahan tipe 2 ditetapkan $10 \%$, sebanyak 32 subjek diperlukan untuk mengetahui hubungan MPV dengan klinis sepsis neonatorum. 47 sampel dipilih menggunakan consecutive sampling. Kriteria inklusi adalah neonatus yang dicurigai sepsis. Sedangkan kriteria ekslusi adalah neonatus yang mendapat terapi antibiotik sebelumnya, neonatus yang pernah menerima transfusi darah sebelumnya, neonatus dengan anomali kongenital berat. Adapun klasifikasi MPV menggunakan nilai batas 10,2 fl dimana $<10,2 \mathrm{fl}$ dikatakan normal dan $>10,2 \mathrm{fl}$ adalah tinggi.

Sumber data dalam penelitian ini adalah berupa data sekunder yang berasal dari rekam medis pasien. Persetujuan penelitian dan penggunaan rekam medis telah disetujui oleh Kepala bagian SMF Anak di RSUD Wangaya Denpasar. Penelitian ini dilakukan analisis univariat untuk mendeskripsikan karakteristik responden. Analisis bivariat dilakukan untuk menghubungkan antara variabel bebas dengan variabel terikat dengan menggunakan uji Chi-Square dan diolah dengan Stastictical Product and Service Solution (SPSS) 23 pada Windows.

\section{HASIL}

Hasil penelitian ini menunjukkan bahwa sebagian besar pasien berjenis kelamin laki-laki $(66,7)$, menjalani persalinan seksio (77,8\%), lahir preterm $(66,7 \%)$, berat badan lahir $(\mathrm{BBL})<2.500$ gram 
Tabel 1 Karakteristik sampel penelitian

\begin{tabular}{|c|c|c|}
\hline \multirow[b]{2}{*}{ Variabel } & \multicolumn{2}{|c|}{ Sepsis $(N=47)$} \\
\hline & Tidak sepsis $(n=27)$ & Sepsis $(n=20)$ \\
\hline \multicolumn{3}{|l|}{ Jenis Kelamin, n (\%) } \\
\hline Laki-laki & $18(66,7)$ & $10(50,0)$ \\
\hline Perempuan & $9(33,3)$ & $10(50,0)$ \\
\hline \multicolumn{3}{|l|}{ Jenis Persalinan, n (\%) } \\
\hline Persalinan seksio (SC) & $21(77,8)$ & $17(85,0)$ \\
\hline Persalinan spontan & $6(22,2)$ & $3(15,0)$ \\
\hline \multicolumn{3}{|l|}{ Usia Kehamilan, n (\%) } \\
\hline Aterm & $9(33,3)$ & $6(30,0)$ \\
\hline Preterm & $18(66,7)$ & $14(70,0)$ \\
\hline \multicolumn{3}{|c|}{ Berat Badan Lahir (BBL), n (\%) } \\
\hline $\mathrm{BBL}>2.500$ gram & $10(37,1)$ & $10(50,0)$ \\
\hline $\mathrm{BBL}<2.500$ gram & $17(62,9)$ & $10(50,0)$ \\
\hline \multicolumn{3}{|l|}{ Keadaan Asfiksia, n (\%) } \\
\hline Iya & $17(62,9)$ & $15(75,0)$ \\
\hline Tidak & $10(37,1)$ & $5(25,0)$ \\
\hline
\end{tabular}

Tabel 2 Hubungan MPV dengan Klinis Sepsis

\begin{tabular}{|c|c|c|c|c|c|c|c|}
\hline \multirow[b]{3}{*}{ Parameter } & \multicolumn{4}{|c|}{ Sepsis } & \multirow[b]{3}{*}{$\mathbf{R R}$} & \multirow[b]{3}{*}{$95 \%$ IK } & \multirow[b]{3}{*}{$\mathbf{p}$} \\
\hline & \multicolumn{2}{|c|}{ Bukan klinis sepsis $(n=27)$} & \multicolumn{2}{|c|}{ Klinis Sepsis $(n=20)$} & & & \\
\hline & $\mathbf{n}$ & $\%$ & $\mathbf{n}$ & $\%$ & & & \\
\hline MPV normal & 21 & 77,8 & 6 & 22,5 & 8,16 & $2,1-30,5$ & 0,003 \\
\hline MPV tinggi & 6 & 30 & 14 & 70 & & & \\
\hline
\end{tabular}

$(62,9 \%)$, dan asfiksia $(62,9 \%)$ pada kelompok tidak sepsis. Sedangkan pada kelompok sepsis sebagian besar menjalani persalinan seksio $(85, \%)$, lahir preterm $(70,0 \%)$, dan asfiksia (75,0\%) (Tabel 1).

Hasil penelitian menunjukkan bahwa terdapat hubungan yang bermakna antara nilai MPV terhadap resiko terjadinya sepsis neonataroum $(\mathrm{p}=0,003)$ (Tabel 2). Berdasarkan analisis resiko yang ditunjukkan dengan penilaian resiko relatif (RR) menunjukkan bahwa terjadinya sepsis neonatarum 8,16 kali lebih tinggi pada pasien dengan kadar MPV yang tinggi (>10,2 fl) dimana nilai 95\% interval kepercayaan (95\% IK) berkisar dari 2,1-30,5 yang mengindikasikan hasil ini dapat digeneralisasikan pada populasi terjangkau (Tabel 2).

\section{PEMBAHASAN}

Sepsis neonatorum merupakan masalah yang sulit dipecahkan dalam pelayanan dan perawatan neonatus, sampai sekarang menjadi penyebab mortalitas dan morbiditas terutama pada negara berkembang. ${ }^{1-3}$ Gambaran klinis pasien sepsis neonatorum tidak spesifik, berbeda dengan sepsis pada populasi anak yang mempunyai gejala klasik sehingga dalam proses diagnosis menjadi sulit walaupun dengan perkembangan ilmu pengetahuan dan teknologi. ${ }^{2,9}$

Platelet telah diketahui mempunyai fungsi dalam proses pembekuan darah dan berdasarkan studi-studi yang dilakukan platelet juga mempengaruhi dalam proses infeksi dan inflamasi. ${ }^{5}$ Jika neonatus dicurigai sepsis maka pasti akan dilakukan pemeriksaan darah lengkap, dan parameter platelet juga terukur dalam pemeriksaan. Salah satu parameter yang terukur adalah MPV dimana merupakan ukuran rata-rata volume platelet dan terekspresikan dalam satuan femtoliter (fL). ${ }^{10}$

Dalam penelitian ini ditemukan bahwa terdapat hubungan bermakna antara MPV dengan klinis sepsis neonatorum secara statistik. Akan tetapi, secara klinis, batas nilai MPV normal adalah 7,5$11,5 \mathrm{fl}$ dimana dalam penelitian ini menggunakan cut-off 10,2 fl maka masih dalam ambang nilai normal. ${ }^{3}$ Sehingga hasil yang diperoleh pada penelitian meski dikatakan bermakna secara statistik, namun tidak bermakna secara klinis. 
Hasil penelitian ini sesuai dengan hasil penelitian yang dilakukan oleh Catal $\mathrm{F}$ et al dimana mereka mengambil sampel neonatus kurang bulan dan menemukan hasil yang bermakna antara kelompok non-sepsis dan sepsis dimana nilai MPV lebih tinggi pada kelompok sepsis. ${ }^{1}$ Sama halnya dengan hasil beberapa penelitian tanpa memandang umur gestasi, mereka juga menemukan nilai MPV lebih tinggi pada grup sepsis., ${ }^{71}$

Peningkatan MPV dalam kondisi sepsis disebabkan oleh peningkatan produksi dan konsumsi platelet, dimana semakin besar ukuran MPV menandakan umur platelet semakin muda. ${ }^{8}$ Produksi platelet dipengaruhi oleh Thrombopetin (Tpo) dan dalam kondisi sepsis sel-sel imunitas mengenali patogen melalui Toll like recepceptors (TLRs) dan selanjutnya melalui TLR platelet dapat mengenali patogen dan meregulasi fungsi imunitas platelet. Dua TLR yang diketahui dapat mempercepat aktivasi platelet yaitu TLR2 dan TLR4. Selain itu kondisi sepsis merangsang produksi Tpo sehingga meningkatkan megakariositopoesis dan pelepasan platelet. ${ }^{3,10}$

Hasil penelitian tidak sesua dengan temuan pada penelitian yang dilakukan oleh Aksoy HT et al., dan Cekmez F et al., pada 152 dan 272 neonatus, dimana tidak ditemukan hubungan antara nilai MPV dengan sepsis. ${ }^{12,13}$ Hal ini mungkin disebabkan oleh perbedaan data demografis penelitian yang keduanya mengambil data dari neonatus berat badan lahir amat rendah (BBLSR) dan berat badan lahir amat sangat rendah (BBLASR) saja. Cekmez F mengatakan bahwa perbedaan hasil penelitian ini bisa oleh karena sepsis dipengaruhi oleh banyaknya faktor dan multifaktorial. Dalam kedua studi ini nilai MPV tidak meningkat oleh karena respon yang inadekuat oleh karena prematuritas. ${ }^{13}$

Selain itu peningkatan nilai MPV juga terjadi pada neonatus kurang bulan yang menderita Bronchopulmonary dysplasia (BPD) dan Necrotizing Enterocolitis (NEC), Intraventricular hemorrhage $(I V H){ }^{10,13}$ Dalam penelitian ini tidak mengeksklusikan penyakit tersebut karena gejala yang muncul mirip dengan sepsis. Selain itu dalam pemeriksaan MPV juga perlu diperhatikan hal teknis seperti waktu dari pengambilan darah ke mesin pemeriksa, antikoagulan yang digunakan, dan adanya clumping dari platelet dan sel darah merah yang bisa mempengaruhi hasil. ${ }^{10,14}$

Beberapa kekurangan dalam penelitian ini adalah tidak adanya sampel yang memiliki kultur positif, sehingga tidak bisa membandingkan antara grup terbukti sepsis dan yang tidak. Selain itu penelitian ini menggunakan satu pusat kesehatan dan jumlah sampel yang kecil dengan kasus yang sebagian besar terdiri atas bayi kurang bulan dan jumlah persalinan terbanyak adalah dengan SC. Kekurangan lain studi ini adalah pengukuran MPV hanya dilakukan sekali saja.

\section{SIMPULAN}

Hasil penelitian ini menunjukkan bahwa terdapat perbedaan yang bermakna antara nilai MPV dengan kejadian sepsis neonatarum dimana terdapat peningkatan resiko terjadinya sepsis neonatorum seiring dengan peningkatan nilai MPV.

\section{PERSETUJUAN ETIK}

Penelitian ini telah disetujui oleh komite etik penelitian kesehatan RSUD Wangaya, Denpasar sebelum penelitian berjalan.

\section{KONFLIK KEPENTINGAN}

Tidak ada konflik kepentingan dalam penelitian ini.

\section{PENDANAAN}

Tidak ada pendanaan dalam penelitian ini.

\section{KONTRIBUSI PENULIS}

Seluruh penulis memiliki kontribusi yang sama dalam penulisan laporan penelitian ini baik dari tahap penyusunan kerangka konsep, pengumpulan data penelitian, analisis data, hingga interpretasi data penelitian dalam bentuk publikasi.

\section{DAFTAR PUSTAKA}

1. Catal F, Tayman C, Tonbul A, Akca H, Kara S, Tatli MM, et al. Mean platelet volume (MPV) may simply predict the severity of sepsis in preterm infants. Clin Lab. 2014;60(7):1193-1200.

2. Kardana M. Incidence and factors associated with mortality of neonatal sepsis. Paediatrica Indonesiana 2011;51(3)144-8.

3. Wilar R, Antolis Y, Tatura SNN, Gunawan S. Jumlah trombosit dan mean platelet volume sebagai faktor prognosis pada sepsis neonatorum. Sari Pediatri. 2010;12(1):53-7.

4. Dharma BDA, Mulyantari NK, Prabawa IPY. Analisis korelasi kadar serum prokalsitonin dengan jumlah leukosit pada penderita dengan kecurigaan sepsis di RSUP Sanglah, Bali, Indonesia. Intisari Sains Medis. 2020;11(1):179-182.

5. Hanaganahalli SB, Sreeram S, Bompada M, Kuppannagari SK, Suresh PK, Philipose CS. Is MPV a Predictive Marker for Neonatal Sepsis? A Pilot Study. J Pediatr Hematol Oncol. 2018;40(7):548-552.

6. Prabawa IPY, Bhargah A, Liwang F, Tandio DA, Tandio AL, Lestari AAW, et al. Pretreatment Neutrophilto-Lymphocyte ratio (NLR) and Platelet-to-Lymphocyte Ratio (PLR) as a Predictive Value of Hematological Markers in Cervical Cancer. Asian Pac J Cancer Prev. 2019;20(3):863-868. 
7. Shalaby MM, Sobeih AA, Abdulghany WE, Behiry EG, Ismail YM, Abd-El-Aziz MA. Mean platelet volume and serum uric acid in neonatal sepsis: A case-control study. Ann Med Surg (Lond). 2017;20:97-102.

8. Van der Lelie J, Von dem Borne AK. Increased mean platelet volume in septicaemia. J Clin Pathol. 1983;36(6): 693-696.

9. Shane AL, Sánchez PJ, Stoll BJ. Neonatal sepsis. Lancet. 2017;390(10104):1770-1780.

10. Bhat YR. Platelet indices in neonatal sepsis: a review. World J Clin Infect. 2017;7(1);6-10.

11. Prathyusha, Shreekrishna GN, Bhat S, Sahana P. Mean platelet volume (MPV) as a diagnostic marker in neonatal sepsis. Int J Contemp Pediatr. 2019;6(3):1036-40.
12. Aksoy HT, Eras Z, Guzoglu N, Canpolat FE, Dilmen U. Mean platelet volume is not associated with bacterial sepsis in newborns. Int J Infect Dis. 2013;17(12):e1263. doi: 10.1016/j.ijid.2013.05.010

13. Cekmez F, Tanju IA, Canpolat FE, et al. Mean platelet volume in very preterm infants: a predictor of morbidities?. Eur Rev Med Pharmacol Sci. 2013;17(1):134-137.

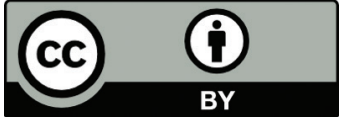

This work is licensed under a Creative Commons Attribution 